\title{
PENGUATAN ORGANISASI DALAM PENGEMBANGAN KAPASITAS DI DINAS KEBUDAYAAN DAN PARIWISATA KOTA BATAM
}

\author{
Karol Teovani Lodan \\ Universitas Putera Batam, Kota Batam, Propinsi Kepulauan Riau, Indonesia \\ karol@puterabatam.ac.id
}

\begin{abstract}
ABSTRAK
Tujuan penelitian ini adalah untuk menga nalisis penguatan organisa si mela lui penerapan aspek manajerialdalam kerangka pengembangan kapasitas (Capacity Building) di Dinas Kebuday a an dan Pariwisata Kota Batam. Metode yang digunakan dalam penelitian ini ada lah kualitatif dengan model deskriptif. Fokus penelitian ada lah penguatan organisasi yang ditinjau dari fokus aktivitas pada penerapan a spek manajerial dalam kerangka pengembangan kapasitas yang terdiri dari : perencanaan, mengerakkan, mengendalikan dan mengevaluasi. Hasil penelitian menunjukkan bahwa penerapan aspek manajerial telah berjalan dengan baik yang tercermin melalui proses perencanaan yakni a danya rencana strategis dan rencana kerja yang da la m penyusunannya melibatkan unit kerja. Pengorganisasian yang telah diatur dan dijalankan sesuai dengan Peraturan Walikota Nomor 58 Tahun 2016 Tentang Tugas Pokok, Fungsi, Uraian Tugas Dinas Kebudayaan dan Pariwisata. Proses mengerakkan atau menga rahkan terlihat pa da kegiatan rapat rutin setiap Hari Senin, menunjukkan peran kepala dan sekretaris dinas dalam memberikan arahan dan pemecahan masalah yang dihadapi oleh unit kerja dalam pelaksanaan tugas. Pada proses pengendalian dilakukan melalui dua cara yakni secara internal dan eksternal. Pengendalian internal dilakukan mela lui mekanisme rapat rutin setiap hari Senin dan pemantauan pertanggungja waban pelaksanaan kegiatan melalui Sistem Pengadaan secara Elektronik (SPSE). Sedangkan pengendalian eksternal dilakukana melalui Rapat Dengar Pendapat (RDP) dilakukan dengan Dua Komisi di Dewan Perwakilan Rakyat Daerah (DPRD) Kota Batam yakni komisi II (bidang ekonomi, keuangan dan industri) dan komisi IV (bidang kesejahtera an rakyat dan sumber daya manusia).
\end{abstract}

Kata Kunci: Penguatan Organisasi, Pengembangan Kapasitas dan Aspek Manajerial

\begin{abstract}
The purpose of this study is to analyze organizational strengthening through the application of managerial aspects within the framework of capacity building (Capacity Building) at the Batam City Culture and Tourism Office. The method used in this study is a qualitative descriptive model. The focus of the research is organizational strengthening in terms of activity focus on the application of managerial aspects within the framework of capacity building which consists of: planning, driving, controlling and evaluating. The results showed that the implementation of managerial aspects had been going well, which was reflected in the planning process, namely the existence of strategic plans and work plans which involved work units in their preparation. Organizing that has been regulated and carried out in accordance with Mayor Regulation Number 58 of 2016 concerning Main Duties, Functions, Job Descriptions of the Culture and Tourism Office. The process of moving or directing is seen in routine meeting activities every Monday, showing the role of the head and secretary of the service in providing direction and solving problems faced by work units in carrying out their duties. The control process is carried out in two ways, namely internally and externally. Internal control is carried out through the mechanism of routine meetings every Monday and monitoring of accountability for the implementation of activities through the Electronic Procurement System (SPSE). While external control is carried out through a Hearing Meeting (RDP) carried out with Two Commissions in the Batam City Regional House of Representatives (DPRD), namely Commission II (economic, finance and industry) and Commission IV (fields of people's welfare and human resources).
\end{abstract}

Keywords: Organizational Strengthening, Capacity Building and Managerial Aspect. 


\section{Kebijakan: Jurnal Ilmu Administrasi \\ Volume 13, Nomor 1, Januari 2022 \\ E-ISSN: 2656-2820 \\ P-ISSN 1829-5762}

\section{PENDAHULUAN}

Momentum otonomi daerah hendaknya dapat dimanfaatkan dengan sebaik-baiknya oleh pemerintah daerah untuk memaksimalkan pembangunan di daerah. Pemerintah daerah dapat memaksimalkan keberadaan perangkat daerah untuk dapat menyalurkan program-program pembangunan agar sejalan dengan kehendak otonomi daerah. Dalam era sekarang ini, pemerintah daerah dihadapkan pada perkembangan teknologi yang semakin canggih, tuntutan masyarakat semakin berkembang, persaingan semakin ketat maka birokrasi perlu melakukan perubahan ke arah penguatan. Penguatan pemerintah daerah dimaksudkan bahwa pembangunan akan lebih berorientasi pada kebutuhan masyarakat di daerah karena mempunyai posisi yang terdekat. Pemerintah daerah menghadapi perubahan dan tantangan dalam memanfaatkan potensi yang dimiliki, salah satunya adalah sektor pariwisata. Pariwisata bukan hanya sekedar berorientasi pada kunjungan wisatawan pada sebuah objek wisata untuk liburan semata melainkan telah menjadi produk bisnis modern. Pariwisatajuga dapat memberikan pengaruh terhadap sektor yang lain seperti lapangan pekerjaan, infrastruktur, pemberdayaan masyarakat, ekonomi daerah atau negara dan taraf hidup masyarakat. Sektor pariwisata telah menjadi tren dalam mengoptimalkan potensi daerah di Indonesia, salah satu yang cukup terkenal adalah Banyuwangi. Banyuwangi memperoleh penghargaan internasional atas kerja kerasnya dalam inovasi pengembangan pariwisata. Banyuwangi mendapatkan penghargaan tertinggi bidang pariwisata tingkat Asia Tenggara, yaitu ASEAN Tourism Standard Award (ASEAN). Penghargaan ini kembali menunjukkan adanya pengakuan internasional terhadap program wisata Banyuwangi.

Sebelumnya, Badan Pariwisata Perserikatan Bangsa-Bangsa (UNWTO) menobatkan Banyuwangi sebagai kawasan dengan inovasi kebijakan pariwisata terbaik dunia 2016 (Muhammad, 2018). Kota Batam sebagai salah satu pintu masuk Indonesia sebelah barat juga memiliki potensi wisata yang besar. Berbatasan dengan negara Singapura dan Malaysia, menjadikan Kota Batam memiliki posisi strategis tidak hanya sebagai pintu masuk Indonesia melainkan sebagai destinasi wisata. Badan Pusat Statistik Kota Batam di Tahun 2017-2018 menyebutkan bahwa waktu menginap wisatawan diantara 1 (Satu) sampai dengan 1 1/2 (Satu Setengah) hari. Rendahnya lama menginap wisatawan mancanegara sehingga sangat berdampak pada transaksi jual beli. Kondisi ini berpengaruh terhadap tingkat spend money (transaksi mengeluarkan uang) dari wisatawan yang berkunjung ke Kota Batam jauh lebih rendah jika dibandingan dengan di Bali. Di Batam, para wisatawan hanya mengeluarkan uang sebanyak 250 Dolar Singapura untuk satu kali kunjungan. Di Bali, dalam sekali kunjungan atau perjalanan, wisatawan menghabiskan uang USD 500 ke atas (Ilham, 2017). Gambaran mengenai kondisi rendahnya waktu menginap wisatawan tentunya memunculkan perhatian yang besar terhadap kapasitas pemerintah daerah dalam mendesain program pariwisata. Upaya untuk meningkatkan kapasitas organisasi dimaksudkan untuk beradaptasi dengan perubahan lingkungan dan tuntutan yang semakin dinamis sehingga mampu berfokus pada pelaksanaan tugas pokok yang dibebankan. Tujuan penelitian adalah untuk menganalisa penguatan organisasi melalui penerapan aspek manajerial dalam kerangka pengembangan kapasitas sebagaimana yang dikemukakan oleh Grindle (1997).

Grindle (1997) mengemukakan bahwa "Capacity building is intended to encompass a variety of strategies tha have to do with increasing the efficiency, effectiveness and responsiveness of government performance" (pengembangan kapasitas merupakan upaya yang ditujukan untuk mengembangkan berbagai strategi untuk meningkatkan efisiensi, efektivitas, dan responsibilitaskinerja pemerintah). Grindle mengungkapkan bahwa pengembangan kapasitas terdiri atas 3 (Tiga) dimensi yakni pengembangan sumber daya manusia, penguatan organisasi dan reformasi kelembagaan yang masing-masing dimensi terdapat jenis aktifitasnya. Dimensi penguatan organisasi fokus nya pada sistem manajemen dalam mengembangkan performa pekerjaan. Prinsip-prinsip manajemen pada umumnya mengacu pada pada yang disampaikan oleh Terry (1977) yakni Planning (perencanaan), organizing 


\section{Kebijakan: Jurnal Ilmu Administrasi \\ Volume 13, Nomor 1, Januari 2022 \\ E-ISSN: 2656-2820 \\ P-ISSN 1829-5762}

(pengorganisasian), actuating (mengerakkan) dan controlling (mengendalikan). Alam \& Prawitno (2015), penelitian dengan judul Pengembangan Kapasitas Organisasi dalam Peningkatan Kualitas Pelayanan Publik Dinas Kehutanan dan Perkebunan Kabupaten Bone, dipublikasikan pada Government: Jurnal Ilmu Pemerintahan, volume 8 nomor 2, halaman 93-103.

Penelitian ini bertujuan untuk menjelaskan pengembangan kapasitas organisasi dalam peningkatan kualitas pelayanan publik pada Dinas Kehutanan dan Perkebunan Kabupaten Bone yang difokuskan pada tiga aspek yaitu pengembangan sumber daya fisik, pengembangan proses operasional dan pengembangan sumber daya manu sia. Penelitian ini menggunakan pendekatan penelitian kualitatif, dengan menyajikan hasil temuan dan kesimpulan analisis dengan menggunakan desain studi kasus. Ratnasari, Makmur \& Ribawanto (2013) penelitian tentang Pengembangan Kapasitas (Capacity Building) Kelembagaan pada Badan Kepegawaian Daerah Kabupaten Jombang, yang dipublikasikan pada Jurnal Administrasi Publik (JAP), volume 1 nomor 3, halaman 103-110. Penelitian ini bertujuan untuk mendeskripsikan dan menganalisis pengembangan kapasitas kelembagaan dan faktor pendukung serta penghambat yang dihadapi dalam pengembangan kapasitas kelembagaan pada Badan Kepegawaian Daerah Kabupaten Jombang.

Penelitian ini menggunakan jenis penelitian deskriptif dengan pendekatan kualitatif. Hapsari dan Djumiarti (2016), penelitian dengan judul Pengembangan Kapasitas (capacity building) Kelembagaan Badan Penanggulangan Bencana Daerah(BPBD) Kabupaten Jepara, dipublikasikan pada Journal of Public Policy and Management Review volume 5 nomor 2. Penelitian deskriptif-kualitatif ini bertujuan untuk mengetahui pengembangan kapasitas kelembagaan kantor kotamadya untuk pencegahan bencana (BPBD) Kabupaten Jepara dalam pencegahan. Syifa (2017), penelitian berjudul Analisis Pengembangan Kapasitas Kelembagaan Pada Badan Kepegawaian, Pendidikan, dan Pelatihan Kota Semarang, diterbitkan pada Journal Of Public Policy And Management Review, volume 6 nomor 2 halaman 215-225.

Penelitian ini bertujuan untuk mengetahui dan menganalisis pengembangan kapasitas kelembagaan di lembaga kepegawaian, pendidikan dan pelatihan di Semarang. Penelitian ini bersifat deskriptif dengan menggunakan jenis pendekatan kualitatif. Yusuf, Sintaningrum dan Utami (2018), penelitian dengan judul Kapasitas Organisasi dalam Meningkatkan Mutu Pendidikan Madrasah di Indonesia, diterbitkan pada jurnal Responsive, volume 1 nomor 1, halaman 1-5. Penelitian ini bertujuan untuk melihat faktor-faktor apa saja yang mempengaruhi kapasitas organisasi Kementerian Agama dalam meningkatkan mutu pendidikan Madrasah Ibtidaiyah di Kabupaten Bandung. Aspek yang digunakan dalam penelitian kualitatif deskriptif ini ialah (1) personnel (sumber daya manusia), (2) infrastucture, technology, and financial resources (infrastruktur, teknologi, dan sumber daya keuangan), (3) strategic leadership (kepemimpinan strategis), (4) program and process management (program dan manajemen proses), dan (5) networking and linkages (jejaring kerjasama dan hubungan dengan pihak lain).

\section{METODE}

Metodologi merupakan penggunaan metode sebagai langkah ilmiah dalam teknis penelitian yang dapat dimulai dari pengumpulan data, analisis, peny ajian data, kesimpulan dan verifikasi hasilnya terhadap berbagai realitas di lapangan. Informasi yang dikumpulkan terkait dengan fenomena yang diamati sebagai yang telah diuraikan diatas tidaklah cukup hanya melalui observasi, tetapi harus menggunakan metode triangulation. Metode yang digunakan dalam penelitian ini adalah kualitatif dengan model deskriptif, bertujuan untuk menguraikan, meringkas berbagai kondisi, berbagai situasi, atau berbagai fenomena realitas sosial yang ada di masyarakat yang menjadi objek penelitian dan 


\section{Kebijakan: Jurnal Ilmu Administrasi \\ Volume 13, Nomor 1, Januari 2022 \\ E-ISSN: 2656-2820 \\ P-ISSN 1829-5762}

berupaya menarik realitas itu ke permukaan sebagai suatu ciri, karakter, sifat, model, tanda, a tau gambaran tentang kondisi, situasi ataupun fenomena tertentu (Burhan, 2015).

Fokus penelitian pada penguatan organisasi dalam kerangka pengembangan kapasitas dengan jenis aktifitas pelaksanaan aspek manajerial. Penentuan informan penelitian dilakukan dengan prosedur purposif yang menggunakan key person. Kunci dasar penggunaan prosedur ini adalah penguasaan informasi dari informan dan secara logika bahwa tokoh-tokoh kunci ini terlibat atau terkait dengan hal yang diteliti. Informan terdiri dari pejabat struktural mulai dari kepala dan sekretaris dinas, kepala bidang, kepala seksi serta staf.

\section{PEMBAHASAN}

Seiring semakin tingginya tuntutan dalam meningkatkan kinerja organisasi, maka perlu dilakukan suatu usaha secara terus menerusagar dapat menghadapi tan tangan ataupun perubahan yang terjadi di masa yang akan datang. Oleh karena itu, organisasi harus meningkatkan kemampuannya yang seiring makin banyaknya kritikan dan tuntutan yang diinginkan. Aspek manajerial menyangkut bagaimana penyelenggaran tugas yang ada pada sebuah organisasi dapat dikelola dengan menggunakan prinsip-prinsip manajemen yang baik sehingga pelaksanaan suatu program atau proyek dapat berjalan optimal. Alam \& Prawitno (2015) mengungkapkan hal lain yang dapat meningkatan kapasitas proses operasional dalam pelaksanaan tugas dan fungsi organisasi adalah kebiasaankebiasaan positif dan nilai-nilai yang berkembang dari hasil interaksi antara pegawai, dan interaksi antara pimpinan dengan pegawai. Penguatan organisasi dalam kerangka pengembangan kapasitas dengan jenis aktifitas pelaksanaan aspek manajerial di Dinas Kebuday aan dan Pariwisata Kota Batam dapat diuraikan sebagai berikut:

Pada aspek perencanaan, terlihat dengan telah adanya panduan pelaksanaan kegiatan pada Rencana Strategis Dinas Kebudayaan dan Pariwisata Kota Batam Tahun 2016-2021. Penyusunan rencara strategis (renstra) melibatkan unit kerja (bidang dan seksi) yang ada di Dinas Kebudayaan dan Pariwisata Kota Batam. Penelitian yang dilakukan oleh Hapsari dan Djumiarti (2016) mengemukakan pentingnya keterlibatan atau partisipasi pegawai dalam perumusan perencanaan sehingga program yang disusun bukan copy paste dari tahun sebelumnyanamun sesuai kebutuhan yang ada. Perencanaan merupakan proses yang membantu manajer atau pimpinan menetapkan tujuan untuk masa datang dan memetakan aktivitas dan sarana yang memungkinkan untuk mencapai tujuan tersebut. Perencanaan sebagaimana yang dikemukakan diatas telah diterjemahkan dalam rencana strategis dan rencana kerja dinas yang memuat tujuan, sasaran, target, program kegiatan serta penggunaan sumber daya yang digunakan dalam kurun waktu Lima tahunan. Hasil dari fungsi perencanaan adalah "rencana (plan)" yang diformulasikan pada suatu dokumen tertulis yang menetapkan serangkaian tindakan yang akan dilaksanakan suatu organisasi. Langkah tersebut tentunya harus dideskripsikan untuk memberikan informasi tentang tindakan yang dapat dilakukan secara strategis. Ketersediaan dokumen proses operasional menjadi pedoman bagi pegawai dalam melaksanakan pekerjaan mereka sehari-hari, sekaligus menjadi panduan dalam memberikan jaminan pelayanan yang berkualitas kepada masyarakat (Alam \& Prawitno, 2015).

Pada aspek pengorganisasian terlihat dengan adanya pengaturan pekerjaan dan sumber daya manusia yang disesuaikan pada unit kerja masing-masing. Uraian tugas danfungsi masing-masing unit kerja yang ada di Dinas Kebudayaan dan Pariwisata Kota Batam diatur melalui Peraturan Walikota Nomor 58 Tahun 2016 Tentang Tugas Pokok, Fungsi, Uraian Tugas Dinas Kebudayaan dan Pariwisata. Selanjutnya dalam pelaksanaan tugas pokok, fungsi, dan uraian tugas sebagaimana yang telah disebutkan diatas, Dinas Kebudayaan dan Pariwisata terdiri dari beberapa susunan yang meliputi 


\section{Kebijakan: Jurnal Ilmu Administrasi \\ Volume 13, Nomor 1, Januari 2022 \\ E-ISSN: 2656-2820 \\ P-ISSN 1829-5762}

sekretariat, kepala bidang dan kepala seksi. Pada susunan unit kerja tersebut, ditempatkan pegawai untuk mendukung pelaksanaan pekerjaan yang diemban. Unit kerja yang ada di dinas sangat berperan penting dalam merealisasikan perencanaan yang telah ditetapkan tanpa terjadinya benturan atau duplikasi kegiatan satu sama lain. Pentingnya pengorganisasian bagi organisasi adalah sebagai mekanisme utama yang digunakan manajer atau pemimpin untuk mengaktifkan rencana, meminimalkan pemborosan, seperti duplikasi usaha dan sumber daya organisasi yang menganggur serta menciptakan dan memelihara hubungan antara semua sumber daya organisasi. Penelitian yang dilakukan oleh Ratnasari, Makmur dan Ribawanto (2013) menunjukkan pengembangan kapasitas sangat ditentukan pada kemampuan organisasi dalam menyusun pekerjaan pada masing-masing bidang sesuai dengan tugas pokok dan fungsi sehingga tidak ada duplikasi pekerjaan serta mendukung pencapian tujuan.

Pada aspek mengerakkan atau mengarahkan para pegawai dalam pelaksanaan tugas, dilakukan melalui mekanisme rapat rutin pada setiap hari Senin. Pada kegiatan ini, kepala dan sekretaris dinas memberikan pengarahan seputar kegiatan yang telah dilaporkan, akan dilaksanakan atau yang menemui kendala. Para pegawai juga dapat mengusulkan masukkan terkait peningkatkan kemampuan mereka seperti penyelenggaraan pelatihan secara mandiri. Semua perihal kegiatan yang dilaksanakan dibahas dalam rapat tersebut dan dirasakan sangat efektif sekali untuk melihat perkembangan pelaksanaan kegiatan. Kepala dan sekretaris dinas menjadikan rapat rutin sebagai ranah berkoordinasi berbagai hal terkait dengan pelaksanaan tugas, meliputi problem dilapangan yang dihadapi pegawai, program pelatihan yang diinginkan, pelaporan, dan evaluasi. Aktivitas rapat bersama juga menjadi bagian koordinasi rutin untuk membangun semangat seluruh pegawai dalam menyelesaikan problem yang dihadapi dan pencapaian target. Kegiatan ini merupakan modal penting dalam mendorong partisipasi pegawai, membangun kesolidan tim dan keberhasilan organisasi. Pimpinan yang responsif dan mampu mengambil keputusan secara tepat dalam pengembangan kapasitas kelembagaan maka akan memberikan pelayanan yang lebih baik. Peranan pemimpin dalam tim beberapa diantaranya adalah memberikan dukungan timbal balik, mengakui prestasi anggota tim, mendorong, dan memudahkan anggota untuk bekerja, berusaha mempertahankan komitmen (Syifa, 2017). Pada aspek ppengendalian (controlling) dilakukan secara internal dan eksternal. Pada pengendalian eksternal, dilakukan dalam bentuk rapat dengar pendapat (RDP) antara Dinas Kebudayaan dan Pariwisata dengan Komisi II (Bidang ekonomi, keuangan dan industri) dan IV (Kesejahteraan rakyat dan sumber daya manusia) Dewan Perwakilan Rakyat Daerah (DPRD) Kota Batam yang dilakukan setiap triwulan sekali dan sesuai kebutuhan mengenai informasi yang dibutuhkan anggota dewan. Kegiatan ini bertujuan menyampaikan informasi capaian yang telah dilakukan dan kendala yang dihadapi sehingga dapat diberikan masukkan oleh anggota dewan selaku representatif mewakili masyarakat Kota Batam.

Rapat dengar pendapat bersama Dewan Perwakilan Rakyat Daerah Kota Batam merupakan sarana dalam pengendalian terhadap pelaksanaan kegiatan baik yang sudah maupun yang belum terealisasi. Pengendalian secara internal dilakukan melalui mekanisme rapat rutin yang dilakukan setiap hari Senin, dan melalui Sistem Pengadaan secara Elektronik (SPSE). Setiap kegiatan yang telah selesai dilaksanakan harus dibuatkan laporan atau yang dikenal dengan sebutan surat pertanggungjawaban (SPJ). Surat pertanggungjawaban merupakan bukti surat yang berkaitan dengan kelengkapan administrasi pertanggungjawaban realisasi kegiatan dan keuangan. Surat pertanggungjawaban wajib kemudian diinputkan ke sistem SPSE. Pemantauan dapat dilakukan dalam sistem SPSE tersebut, mana kegiatan yang telah dilaksanakan namun belum ada laporannya. Dalam hal ini digunakan istilah pengendalian (controlling) bukan pengawasan. Pengawasan berarti mengawasi pegawai yang sedang bekerja, tetapi tidak menilai apakah dia benar atau salah dalam melakukan pekerjaan tersebut. Sedangkan pengendalian disamping melakukan pengawasan kepada 


\section{Kebijakan: Jurnal Ilmu Administrasi \\ Volume 13, Nomor 1, Januari 2022 \\ E-ISSN: 2656-2820 \\ P-ISSN 1829-5762}

pegawai, juga turut serta menilai hasil pekerjaan yang dicapai oleh pegawai. Kapasitas organisasi menjadi perhatian penting untuk pemerintah di dalam menjalankan tugas, pokok dan fungsinya guna memberikan pelayanan kepada publik. Variabel-variabel yang ada pada kapasitas organisasi akan mendukung kinerja dari sebuah organisasi dalam mencapai tujuannya. Jika salah satu variabel mengalami kekurangan maka akan berdampak padakinerja organisasi tersebut dan akan menimbulkan masalah. Maka dari itu organisasi dituntut untuk bisa meningkatkan kapasitas organisasi untuk mencapai tujuan dan menyelesaikan masalah yang di hadapinya (Yusuf, Sintaningrum dan Utami, 2018).

\section{SIMPULAN}

Berdasarkan pembahasan yang telah dilakukan diatas, maka dapat ditarik kesimpulan bahwa penerapan aspek manajerial secara umum yang meliputi Planning (perencanaan), Organizing (pengorganisasian), Actuating (mengerakkan) dan Controlling (pengendalian) telah berjalan di Dinas Kebudayaan dan Pariwisata Kota Batam. Penerapan aspek manajerial adalah upaya strategis dalam menentukan keberhasilan Dinas Kebudayaan dan Pariwisata dalam melaksanakan program kegiatan. Secara keseluruhan penerapan aspek manajerial telah berjalan baik dan memberikan dukungan terhadap penguatan organisasi dalam pelaksanaan tugas yang diberikan. Penguatan organisasi merupakan suatu upaya dalam mempengaruhi kapasitas dinas dalam melaksanakan tugas dibawah kendali yang dimiliki. Selain itu, penguatan organisasi melalui penerapan aspek manajerial juga menunjukkan kekuatan organisasi dalam merancang, mengatur, mengerakkan dan mengevaluasi sehingga dapat menyiapkan penyusunan kegiatan baru kedepannya yang disesuaikan dengan tuntutan dan harapan yang diarahkan ke Dinas Kebudayaan dan Pariwisata Kota Batam.

\section{DAFTAR PUSTAKA}

Alam, Andi Samsu dan Prawitno, Ashar. (2015). Pengembangan Kapasitas Organisasi dalam Peningkatan Kualitas Pelayanan Publik Dinas Kehutanan dan Perkebunan Kabupaten Bone. Government: Jurnal Ilmu Pemerintahan, 8 (2), 93-103.

Grindle, M.S., 1997, Getting Good Govemment: Capacity Building in the Public Sectors of Developing Countries, Boston, MA: Harvard Institute for International Development.

Hapsari, Adhela Mahda dan Djumiarti, Titik. (2016). Pengembangan Kapasitas (capacity building) Kelembagaan Badan Penanggulangan Bencana Daerah (BPBD) Kabupaten Jepara. Journal of Public Policy and Management Review, 5 (2) 1004-1015.

Ilham, Safutra. (2017, Mei 11). Pengembangan Wisata di Batam itu-itu saja. Jawa Pos. diakses dari https://www.jawapos.com.

Muhammad, I. A. (2018, Februari 2). Mengintip Dampak Ekonomi yang Dirasakan Banyuwangi dari Pariwisata. Travel Kompas. Diakses dari https://travel.kompas.com.

Ratnasari, Jenivia, D., Makmur, Mochamad., \& Ribawanto,Heru. (2013). Pengembangan Kapasitas (Capacity Building) Kelembagaan pada Badan Kepegawaian Daerah Kabupaten Jombang. Jurnal Administrasi Publik (JAP), 1 (3), 103-110.

Syifa, D. (2017). Analisis Pengembangan Kapasitas Kelembagaan Pada Badan Kepegawaian, Pendidikan, dan Pelatihan Kota Semarang. Journal Of Public Policy And Management Review, $6(2), 215-225$.

Terry, G.R. (1977). Principle of Management. USA: Richards D. Irwins.

Yusuf, Ningrum, F., Sintaningrum \& Utami, Sawitri, B. (2018). Kapasitas Organisasi dalam Meningkatkan Mutu Pendidikan Madrasah di Indonesia. Responsive, 1 (1), 1-5. 